\title{
The Importance of Website in Business Promotion
}

\author{
S Nurhayati ${ }^{1}$, Abdurrahman $^{2}$ \\ \{ sri.nurhayati@email.unikom.ac.id ${ }^{1 \text { abdurrahman@ mahasiswa.unikom.ac.id }}{ }^{2}$ \} \\ Departemen Teknik Komputer, Universitas Komputer Indonesia, Bandung, Indonesia ${ }^{12}$

\begin{abstract}
This study aims to explain the importance of a website that plays a vital role in a business. This study used the observation method that has been observed related to the use of knowledge management in companies that implement a knowledge management system in it. Entrepreneur surely will be success with some appropriate strategies and promotions. The results of this study are Entrepreneurs must take advantage and the opportunities in choosing the right way to promote as well as use the right platform, either using conventional methods or using media websites. The conclusion is that using a website will help entrepreneurs in developing their business by expanding the reach of it.
\end{abstract} \\ Therefore, the website is a significant role in doing business.
}

\section{Keyword : Business, Promotion, marketing}

\section{Introduction}

Traditional business patterns are entering the internet era in the present day, where traditional patterns have gradually changed from the automation system that uses advanced technology to this process can be called business evolution [1]. Promotions are interpreted as being able to communicate with customers as someone who is offering products, and promotion is a critical role in determining market success [2]. Internet reception in the world causes a profound transformation. The way people communicate and obtain information where consumers understand about the company or the product they produce through the website [3]. Making a marketing strategy in business have several factors that must be considered such as products and promotions that are carried out [4]. To explain that the company uses web analytics which offers a company metric system to measure digital marketing performance. [5]. Marketing needs to have high-quality promotional content and chooses the right way to promote [6]. The latest media information by the company is a website because it is considered as the most intermediate point by customers when searching for product information which more detailed and considered as a more effective way by using print media [7, 8]. Comparative Qualitative Analysis (QCA) interprets the data qualitatively which also looking at the causation between each variable. The stage of this approach will study the causation itself, and the first is a qualitative stage and then systematically uses Qualitative Comparative Analysis (QCA). Qualitative Comparative Analysis (QCA) is a type of a mixedmethod approach in conducting research. The data handling uses simple qualitative data tables. The matrix itself consists of rows and columns. Qualitative Comparative Analysis (QCA) is the most suitable analysis for small-to-medium study project which has many cases [9]. This comparative analysis is one of the old modes of research. It is widely used in many fields especially in the scientific inquiry, the strategy method that uses essential parts in a variety of humanities and social sciences, which can be traced back to antiquity, but more fashionable and also evolving.

The purpose of this study is to prove that the promotion of using the website is more effective than using conventional methods.

\section{Material and Method}

This study used the observation method that observed related to the use of knowledge management in companies which implement a knowledge management system in it. 
Knowledge Management is to organise documentation so that it will become a competitive advantage for companies.

\section{Results and Discussion}

The result of this research is to indicate that the growth of Technology. The growth itself is so fast. The more technology grows, the more businessman can find out many ways to offer something to the consumer. One of the ways to offer in this sophisticated era is uses of the Internet. The internet can help a lot the businessman to introduce the products of their products widely to the consumers via Website through the Internet. With the existence of the Website, the scope of the promotions is on the Worldwide levels because everyone can access the websites from everywhere and anytime, compared with the conventional way that still uses the brochures and others conventional media have low levels of scope. The businessman must care about consumer satisfaction. One of the consumer satisfaction from the website is the Ease of the information to get, until the ease of the transaction because the existence of the Internet, compared with the conventional one. The consumer can easily know the detail and the stock of the products. Also, the last, the profit will grow high compared with the conventional one.

With the uses of the websites, it can reduce the operational costs compared with the conventional, because everything's is a Data on the cloud storage, The Internet. With this way, the businessman can easily find a partner relation too because the website is including the personal company information that can be accessed with another businessman who opens the "About Us" menu at the end of the pages. The other businessman can easily see the potential of the company itself that can lead to being a partner with our business. Understanding the marketing process and strategic planning. 1. Marketing: creating value 2. Customer retention and business profits 3 . Strategic planning and marketing 4. Marketing plans. [11]

This is an example of an initial display brochure that has been published online that can be accessed by anyone who has the URL link. Users can freely choose the information they want to see on the available menu shown in Fig 1.

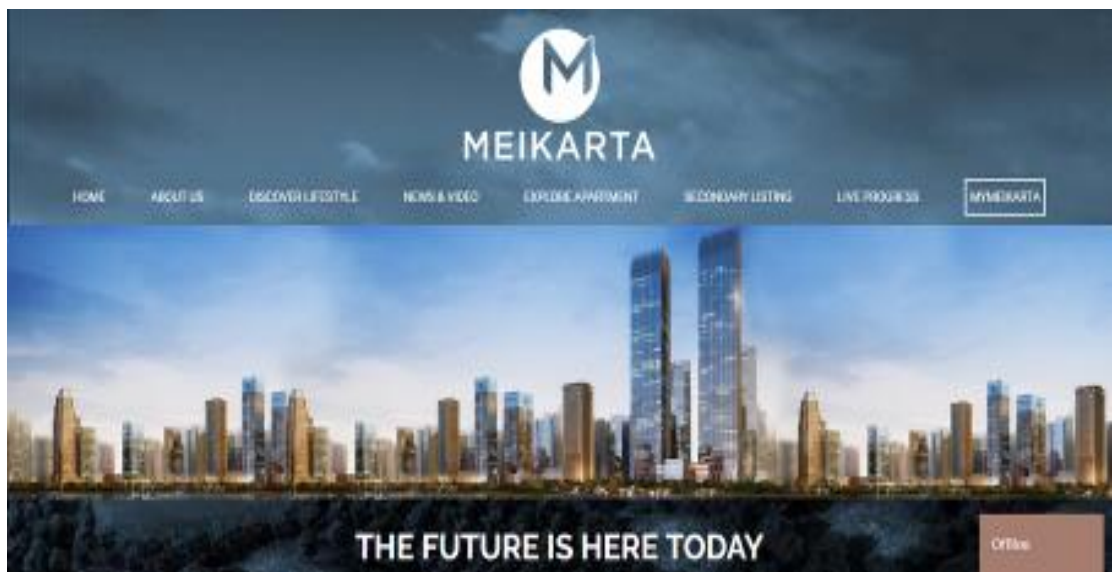

Fig 1. Initial Display.

Next is the Main Menu Preview which has several Sub Menu. Each Sub Menu has its explanation details after choosing shown in Fig 2. 


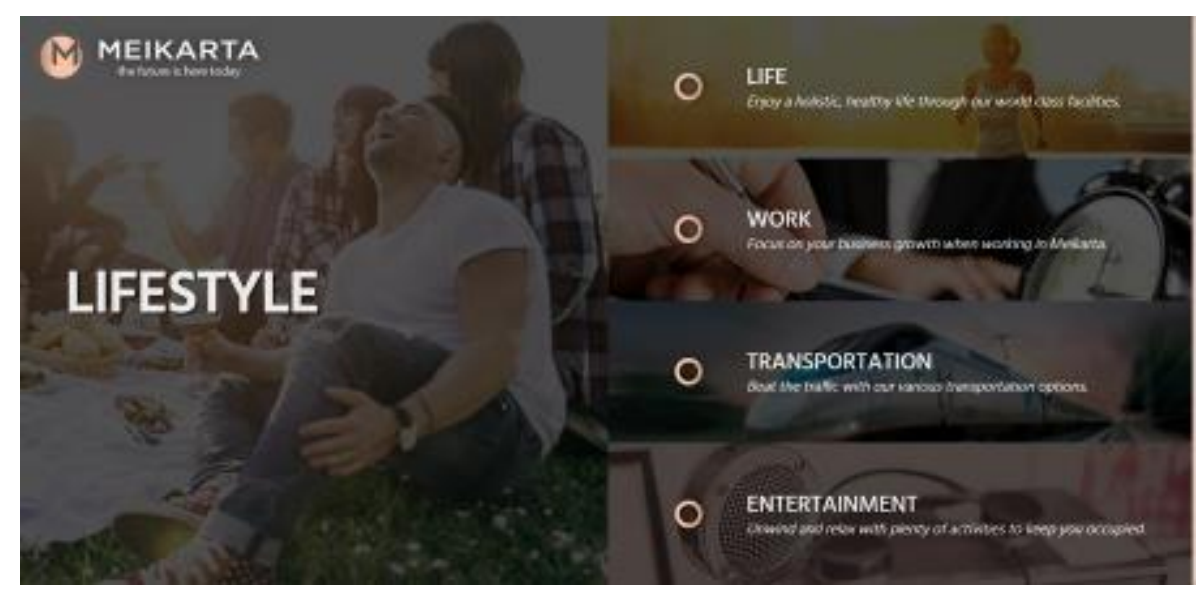

Fig 2. Main Menu Preview.

In the First Sub Menu is "Life". Here the Sub Menu explains that companies care about Life consumers (such as Shopping Needs, Educational Needs, Parks, and Consumer Health) shown in Fig 3.

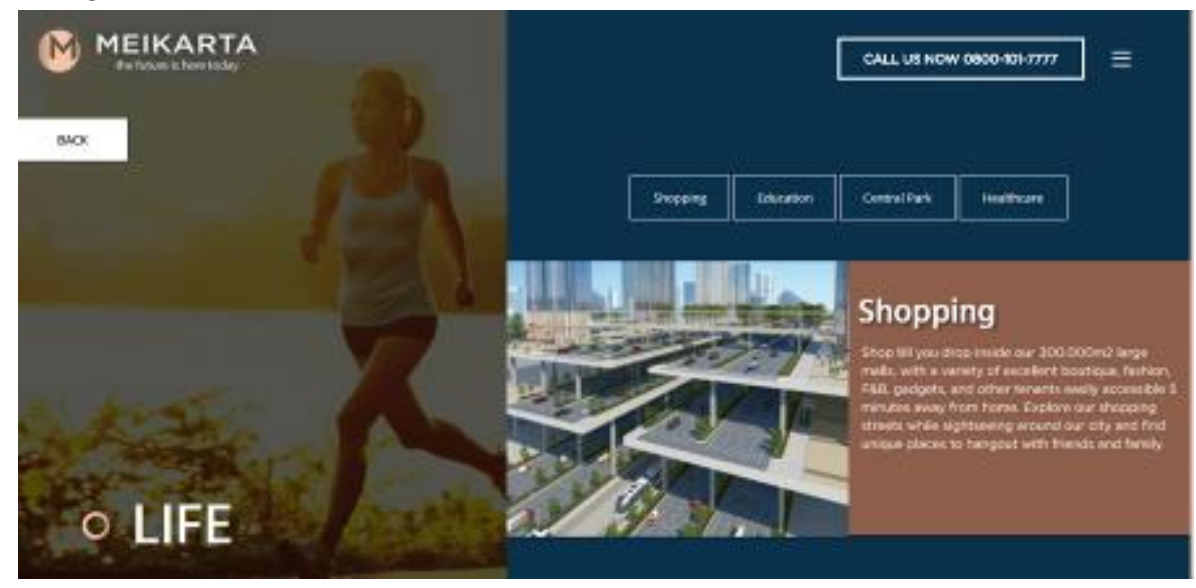

Fig 3. Sub Menu.

This is a display of both company features. The company offers work needs to consumers such as Individual Parking, Economic Center, Business Services, and also International hotels for Work Needs shown in Fig 4.

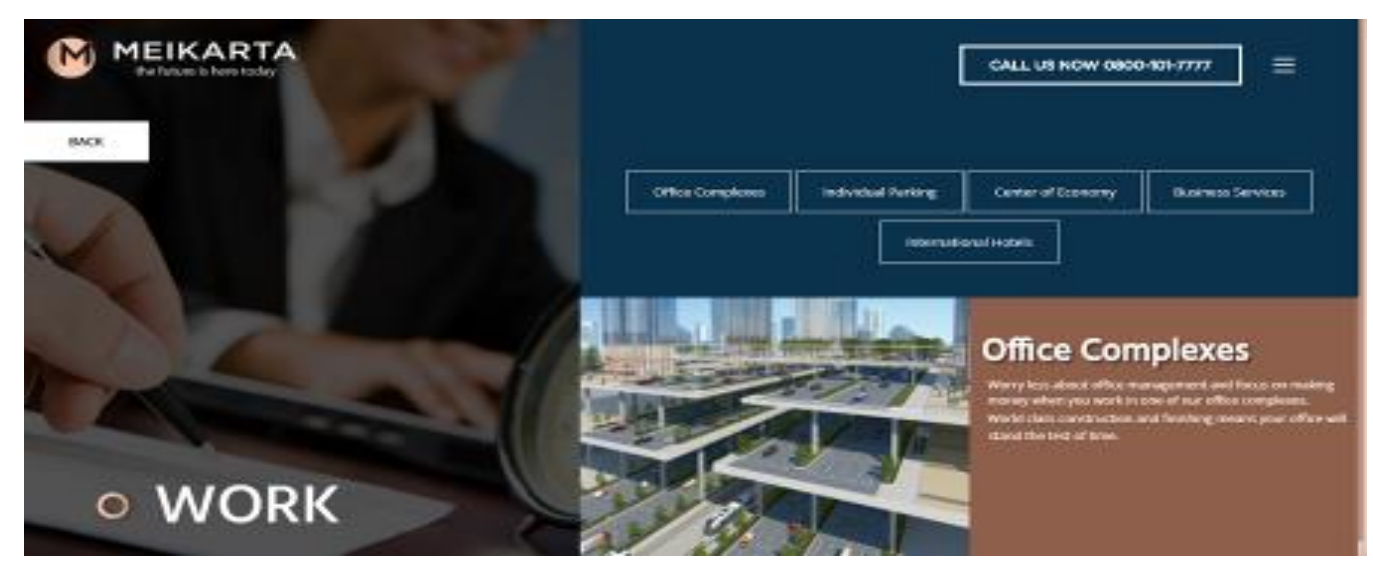

Fig 4. Display of Both Company Future.

In this display there are three features are offered to consumers about transportation needs. Submenus are about roads, tolls, express trains, to international ports shown in Fig 5. 


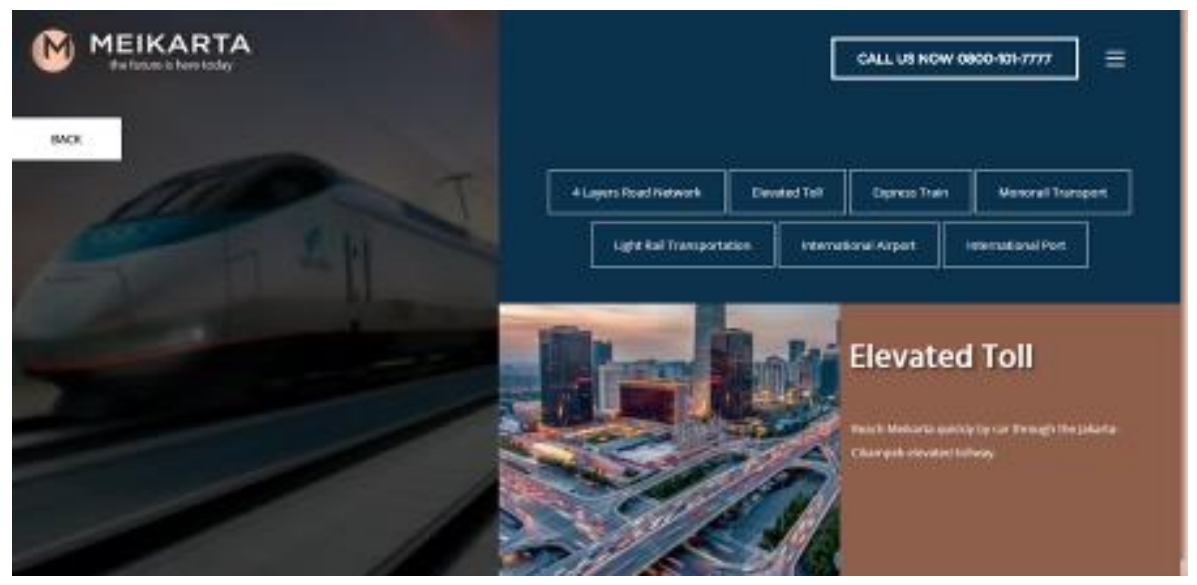

Fig 5. The submenu is about roads, tolls.

This is the last of the preview features that offer to consumers. This feature explains about companies that care about entertainment needs by consumers. The company offers features such as Theater Center, City Library, Convention Center, to Sports Centers shown in Fig 6.

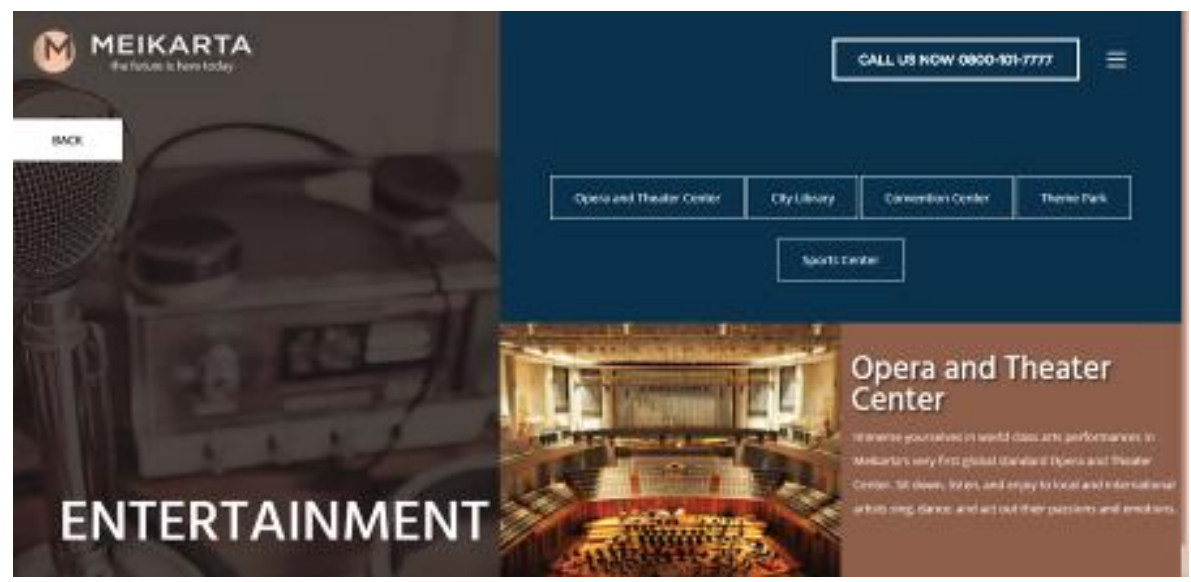

Fig 6. The company offers features.

This is one example of promotional media that uses conventional media. on the information brochure that is conveyed is very limited to the brochure made simple so that it is easily understood by consumers. Not all features/products on the brochure can be seen more pages used will cost more. The brochure has an agreement if the company wants to update information such as new facilities or price changes that occur when running it. By using brochures all must start from the beginning with a new brochure with display and updated information. The reach of media promotions using brochures is not so broad as just a city shown in Fig 7.

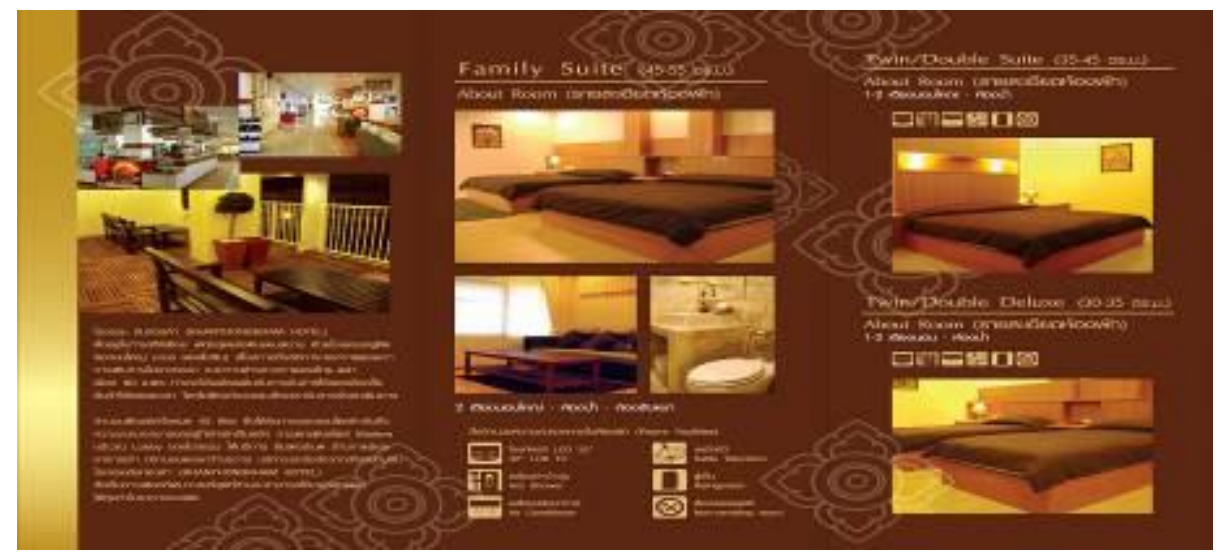

Fig 7. Promotional media that use conventional media. 
Table I. Comparison of the promotion of using media websites with conventional media.

\begin{tabular}{|c|c|c|}
\hline \multirow{3}{*}{ Factor } & \multicolumn{2}{|c|}{ Comparison } \\
\hline & & Promoting Using Conventional Media \\
\hline & \multicolumn{2}{|l|}{ Website Promotion } \\
\hline Cost & $\begin{array}{l}\text { The cost is far more economical if } \\
\text { compared to promotions using } \\
\text { brochure / newspaper media with } \\
\text { promotion using the website } \\
\text { generally only costs under } \\
\text { Rp } 700.000 \text { per month }\end{array}$ & $\begin{array}{l}\text { For the cost of making brochures } / \\
\text { newspapers is relatively cheap, but if done } \\
\text { repeatedly it will obviously harm the } \\
\text { company }\end{array}$ \\
\hline Speed & $\begin{array}{l}\text { Always connect with customers by } \\
\text { always updating new products or } \\
\text { special promotions or new services } \\
\text { provided }\end{array}$ & $\begin{array}{l}\text { Promotion using brochures / newspapers } \\
\text { from the beginning of the making requires a } \\
\text { long time to arrive in the hands of } \\
\text { consumers }\end{array}$ \\
\hline Scope & $\begin{array}{l}\text { Can reach a wider target market } \\
\text { because everyone can access the } \\
\text { website while connected to the } \\
\text { internet network }\end{array}$ & $\begin{array}{l}\text { The reach of marketing using brochures is } \\
\text { not too broad, only limited to a region or } 1 \\
\text { city }\end{array}$ \\
\hline Information & $\begin{array}{l}\text { With promotions using online } \\
\text { websites / catalogues can provide } \\
\text { more information about the product } \\
\text { or service being promoted }\end{array}$ & $\begin{array}{l}\text { With the promotion of using brochures, it is } \\
\text { usually reviewed to be more simple, directly } \\
\text { focused on the point that is promoted so that } \\
\text { consumers can immediately understand the } \\
\text { intended purpose, but remain in limited } \\
\text { explanation }\end{array}$ \\
\hline
\end{tabular}

Table 1 explains the comparison between the promotions of using media websites with conventional media from various aspects.

\section{Conclusion}

Conclusions based on views (numbers) and comparison tables, we can easily see that nonconventional ways prevail in this sophisticated age. Promotional costs in a conventional way are higher than non-conventional ones. In terms of non-conventional speed, always connect with consumers because the product or service can be updated anytime with Internet usage. The range of non-conventional ways is "Worldwide" because everyone who has the Internet can access the website. Also, lastly, the information contained on the Website can explain the product in more detail because there are no restrictions when compared to the conventional method of promotion, the details of which must be made as simple as possible due to lower costs.

\section{References}

[1] Soegoto, E. S., Delvi, J., \& Sunaryo, A.: Usage of E-commerce in Increasing Company Power and Sales. In IOP Conference Series: Materials Science and Engineering (Vol. 407, No. 1, p. 012035). IOP Publishing (2018).

[2] Rowley, J.: Promotion and marketing communications in the information marketplace. Library review, 47(8), pp. 383-387, (1998).

[3] Christ, P.: Internet technologies and trends transforming public relations. Journal of Website Promotion, 1(4), 3-14 (2007).

[4] Hammouri Q, \& Abu-Shanab E.: Exploring Factors Affecting Users' Satisfaction Toward ELearning Systems.International Journal of Information and Communication Technology Education (IJICTE) 14(1) pp. 44-57,(2018).

[5] Järvinen, J, \& Karjaluoto H.: The use of Web analytics for digital marketing performance measurement. Industrial Marketing Management, 50 pp. 117-127 (2015).

[6] Baltes L P.: Content marketing-the fundamental tool of digital marketing. Bulletin of theTransilvania University of Brasov Economic Sciences Series V 8(2) pp. 111,(2015).

[7] Nizam N Z, Jaafar J A, and Supaat S H.: Interactive Online Advertising: The Effectiveness of Marketing Strategy towards Customers Purchase Decision In MATEC Web of Conferences 150(05043) EDP Sciences p. 6,(2018).

[8] Mahajan P, and Suresh G.: E-Promotion: A Revolution in Technical Education Evolution Shirpur Department of Economics 5(1) pp. 1-7 (2017). 
[9] Olsen, W.: Qualitative Comparative Analysis. Retrieved from The University of Manchester qualitative methods qualitative comparative analysis (2010).

[10] Azarian, R.: Potentials and limitations of comparative method in social science. International Journal of Humanities and Social Science, 1(4), 113-125 (2011).

[11] Kotler, P., Burton, S., Adam, S., Brown, L., \& Armstrong, G.: Marketing. Pearson Education Australia (2007). 